\title{
HUBUNGAN STATUS GIZI DENGAN PERKEMBANGAN MOTORIK PADA ANAK USIA 3 - 5 TAHUN
}

\author{
Mimi Ruspita ${ }^{1}, K_{\text {hobibah }}{ }^{2}$ \\ 1,2,UPP Kampus Kendal, Poltekkes Kemenkes Semarang, Indonesia
}

\begin{abstract}
An important period in growth and development is the toddler period, so that the slightest abnormality or deviation if it is not detected and not handled properly, will reduce the quality of human resources in the future. (Ministry of Health RI, 2016). A preliminary study conducted in Bandengan village in early 2019 on 5 children under five with malnutrition status, 3 children (60\%) experienced delays in fine motor aspects, 2 children (40\%) experienced delays in gross motor aspects. The purpose of this study was to determine the relationship between nutritional status and gross and fine motoric development. Quantitative research method with cross sectional approach. The population of all children aged 3-5 years in Bandengan village, Kendal Regency who meets the inclusion and exclusion criteria is 144 people as a sample. Univariate data analysis with frequency distribution and bivariat analysis with Chi Square test with a 0,05. The results showed that there was a significant relationship between nutritional status and gross motor skills of children aged 3-5 years where the $p$ value was $0.001<\alpha 0,05$, and there was a significant relationship between nutritional status and fine motor skills of children aged 3-5 years with $p$ value $0.001<\alpha 0,05$
\end{abstract}

Keywords : nutritional status; gross motor skills; fine motor skills 


\section{PENDAHULUAN}

Periode penting dalam tumbuh kembang adalah masa balita. Pada masa ini perkembangan kemampuan berbahasa, kreatifitas, kesadaran sosial, emosional dan intelegensia berjalan cepat dan merupakan landasan perkembangan berikutnya, sehingga kelainan atau penyimpangan sekecil apapun apabila tidak terdeteksi dan tidak ditangani dengan baik, akan mengurangi kualitas sumber daya manusia di kemudian hari. (Kemenkes RI, 2016)

Salah satu faktor yang berpengaruh terhadap tumbuh kembang anak adalah lingkungan postnatal yaitu gizi (Kemenkes RI, 2016). Status gizi balita merupakan hal yang harus diketahui oleh setiap orang tua, perlunya perhatian lebih dalam tumbuh kembang di usia balita didasarkan fakta bahwa kurang gizi yang terjadi pada masa emas ini, bersifat irreversible/tidak dapat pulih. (Soetciningsih, 2015)

Penelitian yang dilakukan oleh Alfarizi di Kota Palembang disimpulkan status gizi memiliki pengaruh pada perkembangan anak, di mana jika gizi yang dikonsumsi belum terpenuhi dengan baik maka perkembangan akan terhambat. (RD Fatonah, 2011) Sedangkan penelitian yang dilakukan oleh Waoran di Kelurahan Bitung Kecamatan Amurang Kabupaten Minahasa Selatan, didapatkan hasil bahwa perkembangan motorik kasar yang sesuai memerlukan kecukupan gizi yang optimal. (Waoran, 2016) Adapun penelitian lain yang dilakukan Kasenda di TK GMIM Solafide Kelurahan Kaer Kecamatan Kawang Koar Induk Kabupaten Minahasa ditemukan hasil penelitian terdapat hubungan yang bermakna antara status gizi dengan perkembangan motorik halus anak usia prasekolah. (Kasenda, 2015)

Studi pendahuluan yang dilakukan di desa Bandengan pada awal tahun 2019 terhadap 5 anak balita dengan status gizi kurang didapatkan 3 anak umur 3 dan 4 tahun $(60 \%)$ mengalami keterlambatan pada aspek motorik halus, 2 anak umur 3 tahun (40\%) mengalami keterlambatan pada aspek motorik kasar, sedangkan pada perkembangan bahasa dan personal sosial tidak ada yang mengalami keterlambatan. Sehingga peneliti tertarik melakukan penelitian hubungan status gizi dengan perkembangan motorik di Kelurahan Bandengan Kendal.

\section{METODOLOGI PENELITIAN}

Penelitian ini merupakan penelitian kuantitatif dengan pendekatan cross sectional. Adapun waktu pelaksanaan Oktober 2019. Populasinya semua anak usia 3-5 tahun di Kelurahan Bandengan Kecamatan Kendal Kabupaten Kendal berjumlah 172 orang. Pengambilan sampel menggunakan total populasi namun yang memenuhi kiteria inklusi dan eksklusi sejumlah sampel yaitu 144 orang. Cara pengumpulan data dengan pengukuran berat badan dan pemeriksaan 
perkembangan menggunakan form DDST II sesuai umur. Analisis data univariat dengan distribusi frekuensi dan analisis bivariat dengan Uji Chi Square dengan nilai $\alpha 0,05$

\section{HASIL PENELITIAN DAN BAHASAN}

1. Karakteristik Responden

Gambar 1 Jenis Kelamin Responden Jenis Kelamin Responden

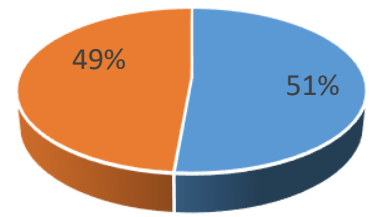

- Laki-laki

- Perempuan

Sebagian besar jenis kelamin responden laki-laki

Gambar 2 Umur Responden

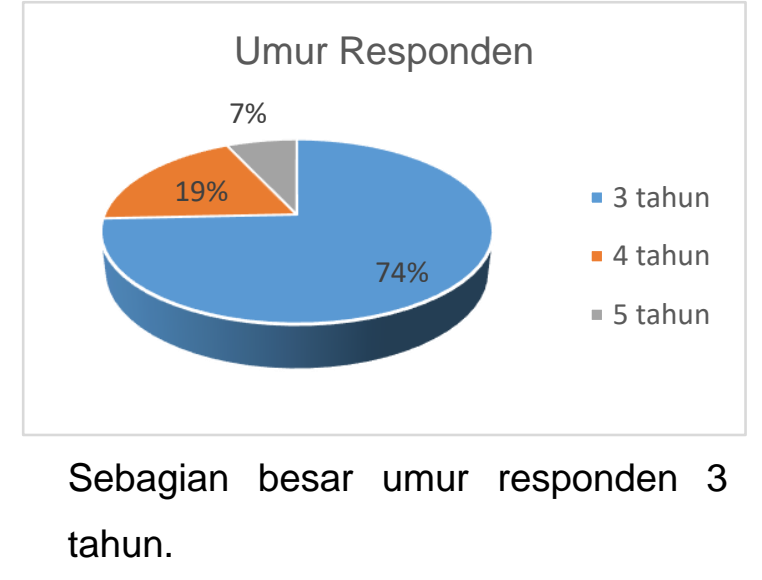

2. Status Gizi

Tabel 1. Status Gizi Responden

\begin{tabular}{|l|c|c|}
\hline \multicolumn{1}{|c|}{ Status Gizi } & $f$ & $\%$ \\
\hline Kurang & 26 & 18,0 \\
Baik & 113 & 78,5 \\
Lebih & 5 & 3,5 \\
\hline \multicolumn{1}{|c|}{ Jumlah } & 144 & 100 \\
\hline
\end{tabular}

Sebagian besar responden memiliki status gizi baik sebanyak 113 responden $(78,5 \%)$, namun masih ada responden yang memiliki status gizi kurang 26 responden (18\%).

3. Perkembangan Motorik Kasar Tabel 2. Motorik Kasar Responden

\begin{tabular}{|l|c|c|}
\hline Motorik Kasar & $f$ & $\%$ \\
\hline Terlambat & 16 & 11,1 \\
Tidak & 128 & 88,9 \\
Terlambat & & \\
\hline \multicolumn{1}{|c|}{ Jumlah } & 144 & 100 \\
\hline
\end{tabular}

Dari 144 responden masih ada 11 responden $(7,6 \%)$ yang motorik kasarnya terlambat.

4. Perkembangan Motorik Halus Tabel 3. Motorik Halus Responden

\begin{tabular}{|l|c|c|}
\hline Motorik Halus & $\mathrm{f}$ & $\%$ \\
\hline Terlambat & 28 & 19,4 \\
Tidak & 116 & 80,6 \\
Terlambat & & \\
\hline \multicolumn{1}{|c|}{ Jumlah } & 144 & 100 \\
\hline
\end{tabular}

Dari 144 responden masih ada 28 responden $(19,4 \%)$ yang motorik halusnya terlambat. 
5. Hubungan Status Gizi dengan Motorik Kasar

Tabel 4. Hubungan Status Gizi dengan Motorik Kasar

\begin{tabular}{|l|c|c|c|c|}
\hline \multirow{2}{*}{$\begin{array}{c}\text { Status } \\
\text { Gizi }\end{array}$} & \multicolumn{2}{|c|}{ Motorik Kasar } & \multirow{2}{*}{ Total } & $\begin{array}{c}\mathrm{x}^{2} \\
\text { Hitung }\end{array}$ \\
\cline { 2 - 3 } & Terlambat & $\begin{array}{c}\text { Tidak } \\
\text { Terlambat }\end{array}$ & & 0,001 \\
Kurang & $14(53 \%)$ & $12(47 \%)$ & $26(100 \%)$ & $0,13(100 \%)$ \\
Baik & $1(1 \%)$ & $112(99 \%)$ & 113 \\
Lebih & $1(20 \%)$ & $4(80 \%)$ & $5(100 \%)$ & \\
& & & & \\
\hline Total & 16 & 128 & 144 & \\
\hline
\end{tabular}

Responden yang memiliki status gizi kurang sebagian besar motorik kasarnya terlambat yaitu 14 responden (53\%) dan responden yang memiliki status gizi baik sebagian besar motorik kasarnya tidak terlambat yaitu 112 responden (99\%) dengan hasil uji chi square $p=0,001<\alpha 0,05$ maka terdapat hubungan yang signifikan antara status gizi dengan motorik kasar. Hal ini dapat diartikan pula bahwa status gizi anak mempunyai korelasi dengan ketrampilan motorik kasarnya.

Perkembangan anak erat hubungannya dengan maturasi sistem susunan saraf. Sedangkan maturasi sistem susunan saraf sangat dipengaruhi asupan gizi inilah yang disebut status gizi. (Kemenkes, 2015)

Seperti penelitian Fatriansari (2018) terdapat hubungan yang signifikan antara status gizi dengan perkembangan motorik kasar dengan $\mathrm{p}$ value $0,006<0,05$. Begitu pula dengan penelitian Timuda (2014) didapatkan hasil 29,5\% responden mengalami

keterlambatan

perkembangan motorik kasar yang terdiri dari 3,3\% responden sangat kurus, $7,4 \%$ responden kurus,15,6\% responden normal dan 3,3\% anak gemuk, dengan nilai $p$ sebesar 0,000 dan $\alpha=0,05$ artinya terdapat hubungan yang sangat signifikan antara status gizi dengan perkembangan motorik kasar.

6. Hubungan Status Gizi dengan Motorik Halus

Tabel 5. Hubungan Status Gizi dengan

\begin{tabular}{|c|c|c|c|c|}
\hline \multicolumn{5}{|c|}{ Motorik Halus } \\
\hline \multirow{2}{*}{$\begin{array}{c}\text { Status } \\
\text { Gizi }\end{array}$} & \multicolumn{2}{|c|}{ Motorik Halus } & \multirow{2}{*}{ Total } & \multirow{2}{*}{$\begin{array}{c}x^{2} \\
\text { Hitung } \\
\end{array}$} \\
\hline & Terlambat & $\begin{array}{c}\text { Tidak } \\
\text { Terlambat }\end{array}$ & & \\
\hline Kurang & $18(69 \%)$ & $8(31 \%)$ & $26(100 \%)$ & 0,001 \\
\hline Baik & $8(7 \%)$ & 105 (93\%) & $113(100 \%)$ & \\
\hline Lebih & $2(40 \%)$ & $3(60 \%)$ & $5(100 \%)$ & \\
\hline Total & 28 & 116 & 144 & \\
\hline
\end{tabular}

Responden yang memiliki status gizi kurang sebagian besar motorik halusnya terlambat yaitu 18 responden (69\%) dan responden yang memiliki status gizi baik sebagian besar motorik halusnya tidak terlambat yaitu 105 responden (93\%) dengan hasil uji chi square $p=0,001<\alpha 0,05$ maka terdapat hubungan yang signifikan antara status gizi dengan motorik halus. Hal ini dapat diartikan pula bahwa status gizi anak mempunyai korelasi dengan ketrampilan motorik halusnya. 
Seperti penelitian Pasapan

(2014) terdapat hubungan yang signifikan antara perkembangan motorik dengan status gizi menurut BB/U pada anak usia 1-3 tahun.

Ketrampilan motorik halus merupakan koordinasi halus pada otot-otot kecil yang memainkan suatu peran utama. Pergerakan trampil adalah proses yang sangat kompleks, sehingga faktor-faktor yang berhubungan dengan ketidaktercapaian ketrampilan perlu diminimalkan. (Soetjiningsih, 2015)

\section{KESIMPULAN}

1. Sebagian besar responden memiliki status gizi baik sebanyak 113 responden (78,5\%), namun masih ada responden yang memiliki status gizi kurang 26 responden (18\%).

2. Dari 144 responden masih ada 11 responden $(7,6 \%)$ yang motorik kasarnya terlambat.

3. Dari 144 responden masih ada 28 responden $(19,4 \%)$ yang motorik halusnya terlambat.

4. Ada hubungan antara status gizi dengan perkembangan motrik kasar anak umur 3-5 tahun dengan $p$ value $0,001<\alpha 0,05$

5. Ada hubungan antara status gizi dengan perkembangan motorik halus anak umur 3-5 tahun dengan $p$ value $0,001<\alpha 0,05$

\section{DAFTAR PUSTAKA}

1. Vinayastri (2015), Perkembangan Otak Anak Usia Dini, J. IIm. WIDYA, vol. 3, no. 1, pp. 33-42

2. Alfarizi (2015), Hubungan Status Gizi dengan Perkembangan Anak, Syifa Medika Vol.6 No.1

3. BKKBN (2016), Menyiapkan Anak Yang Sehat Dan Berkualitas, Jakarta,

4. Desminta (2006), Psikologi Perkembangan. Bandung, PT Remaja Rosdakarya

5. Fatimah, Enung (2010), Psikologi Perkembangan (Perkembangan Peserta Didik), Bandung: Pustaka Setia

6. Fatriansari (2018), Hubungan Status Gizi dengan Perkembangan Motorik Kasar Anak, Jurnal ilmiah Multi Science Kesehatan Vol.9 No.1

7. Hidayat, Alimul (2011), Metode Penelitian Kebidanan dan Teknik Analisis, Jakarta : Salemba

8. Hidayat (2011), Metode Penelitian Kebidanan dan Teknik analisis Data, Jakarta: Salemba

9. Kasenda (2015), Hubungan Status Gizi dengan Perkembangan Motorik Halus pada Anak Usia Prasekolah di TK GMIM Solafide Kelurahan Kaer Kecamtan Kawang Koar Induk Kabupaten Minahasa, Jurnal Keperawatan Vol.3 No.1

10. Kementerian Kesehatan RI (2016), Pedoman Pelaksanaan Stimulasi, Deteksi, dan Intervensi Dini Tumbuh Kembang Anak Di tingkat Pelayanan Kesehatan Dasar, Jakarta

11. Khomsah. Ali (2008), Menu Sehat untuk Tumbuh Kembang Anak Usia 624 Bulan Edisi Revisi, Jakarta: Agromedia Pustaka

12. Notoatmodjo (2010), Metodologi Penelitian Kesehatan, Jakarta: Rineka Cipta

13. Oktavianis (2016), Faktor-Faktor yang Berhubungan dengan Status Gizi pada Balita di Puskesmas Lubuk Kilangan, J. Hum. Care, vol. 1, no. 3, pp. 1-12

14. R. D. Fatonah (2011), Faktor-Faktor yang Berhubungan dengan Status Gizi Balita Usia 06-60 bulan di Kelurahan 
Kuto Batu Kecamatan Ilir Timur II Kota Palembang, Progr. Stud. Gizi, pp. 121

15. Soetjiningsih (2015), Tumbuh Kembang Anak, Jakarta: EGC

16. Timuda (2014), Hubungan Status Gizi dengan Perkembangan Motorik Kasar Anak pada Usia Bayi, dan Balita (0-59 bulan) di Puskesmas Pandanwangi Malang, Ejournal UMM Vol.10 No.2

17. Waoran (2016), Hubungan Status Gizi dengan Perkembangan Motorik Kasar Anak Usia 1 -3 tahun, Jurnal Keperawatan Vol.4 No.2

18. Yuriastien. Dkk (2009), Games Terapy untuk Kecerdasan Bayi dan Balita, Jakarta: Wahyu Media

19. Z. Arifin (2016), Gambaran Pola Makan Anak Usia 3 - 5 tahun dengan Gizi Kurag di Pondok Bersalin Tri Sakti Balong Tani Kecamatan Jabon Sidoarjo, Midwifery Vol.1 No.1 